\title{
Cognitively-Based Compassion Training
}

National Cancer Institute

\section{Source}

National Cancer Institute. Cognitively-Based Compassion Training. NCI Thesaurus. Code C154220.

Classes consisting of didactics, class discussion, and guided meditation practice designed to challenge unexamined assumptions regarding feelings and actions toward others with a focus on generating spontaneous empathy and compassion for self and others. 